\title{
A Comparison of the Financial Characteristics of U.S., Canadian, and Mexican Manufacturing Firms
}

\author{
Ilhan Meric ${ }^{1}$, Herbert E. Gishlick ${ }^{1}$, Leonore S. Taga ${ }^{1} \&$ Gulser Meric ${ }^{2}$ \\ ${ }^{1}$ Department of Finance and Economics, Rider University, USA \\ ${ }^{2}$ Department of Accounting and Finance, Rowan University, USA \\ Correspondence: Ilhan Meric, Professor of Finance, Department of Finance and Economics, College of Business \\ Administration, Rider University, Lawrenceville, NJ 086488, USA. E-mail: Meric@rider.edu
}

Received: April 21, 2013

Accepted: May 21, 2013

Online Published: June 20, 2013

doi:10.5539/ijef.v5n7p1

URL: http://dx.doi.org/10.5539/ijef.v5n7p1

\begin{abstract}
Empirical studies show that firms in different countries with integrated economies tend to have similar financial characteristics. In this paper, we test this hypothesis with U.S., Canadian, and Mexican manufacturing firms. The U.S., Canada, and Mexico are members of NAFTA (the North American Free Trade Agreement) which went into effect in 1994. We find that, despite about two decades of economic integration, the financial characteristics of U.S., Canadian, and Mexican manufacturing firms are still significantly different. U.S. manufacturing firms generally have more liquidity and less technical insolvency risk, higher profitability and sales growth rate, and they use less fixed assets in production compared with their Canadian and Mexican counterparts.
\end{abstract}

Keywords: economic integration, financial characteristics, manufacturing firms, MANOVA, U.S., Canada, Mexico, MANOVA (multivariate analysis of variance)

\section{Motivation for the Study}

The U.S., Canada, and Mexico are members of NAFTA (North American Free Trade Agreement). Empirical studies show that free competition, removal of barriers to trade, and free cross-border flow of capital increase economic integration between countries, and firms with integrated economies tend to have similar financial characteristics (see: Stulz, 1981; Gultekin, Gultekin and Penati, 1989; Meric at al., 2007). A study by Aggarwal and Kyaw demonstrate that U.S., Canadian, and Mexican equity markets are integrated. The objective of our study is to test the hypothesis that U.S., Canadian, and Mexican manufacturing firms have similar financial characteristics.

\section{NAFTA and Economic Integration}

The North American Free Trade Agreement went into effect in 1994 and became, in effect, an extension of the 1989 United States-Canada Free Trade Agreement to enable Mexico to become more integrated into the economy of North America. A Free Trade area is not only the most common form of preferential trade agreement, it is also the most basic and simple way to promote economic integration. That is, it only serves to eliminate some or most protective barriers among its members, enabling those members to benefit from the free flow of goods and services across borders, while still allowing them to have their own trade policies vis-à-vis non-member countries. While most economists would prefer multilateral trade accords, these are more difficult to negotiate.

Studying the effect of the NAFTA agreement on manufacturing, Wylie (1995) concluded that there would be significant trade diversion from non-member country manufacturing exports to Canada, Mexico, and the United States but that such diversion would not overwhelm trade creation effects once NAFTA-induced dynamic growth effects were factored in. In addition, a broader industry-based analysis by Karemera and Ojah (1998) covering the ten most traded commodities, excluding automobiles (already covered by a free trade agreement), and using quarterly data covering the period from the first quarter 1980 through the first quarter 1995, found that the NAFTA agreement would produce more trade creation than trade diversion, with the U.S. benefiting most and Mexico the least from its initial trade effects. Subsequent studies documenting the actual impact of NAFTA, including Hillberry and McDaniel (2002) and a more comprehensive study by Hufbaurer and Schott (2005), suggest both a growth in and a broadening of trade and investment resulting in a more efficient and integrated 


\section{North American economy.}

Data from the U.S. Department of Commerce International Trade Administration showing the exports and imports of manufactured goods between the United States and trading partners for the years 1994 and 2012 were used to calculate the shares of manufactured goods traded between the U.S. and Canada, and the U.S. and Mexico. Table 1 presents these percentages and illustrates how these values have changed over the years the NAFTA agreement has been in effect.

Table 1. U.S. exports and imports of NAICS all manufactured goods

\begin{tabular}{lllll}
\hline & $\mathbf{1 9 9 4}$ & & $\mathbf{2 0 1 2}$ & \\
\hline EXPORTS & \$ Billions & Percent & \$ Billions & Percent \\
World & & & & 100.0 \\
Canada & 448.7 & 100.0 & $1,347.0$ & 19.4 \\
Mexico & 103.9 & 23.1 & 261.5 & 14.5 \\
IMPORTS & 45.5 & 10.1 & 195.1 & 100.0 \\
World & & & & 11.9 \\
Canada & 568.2 & 100.0 & 215.1 & 12.3 \\
Mexico & 105.7 & 18.6 & 222.6 & \\
\hline
\end{tabular}

Source: Figures are derived from National Trade data supplied by the U.S. Department of Commerce. International Trade Administration. Office of Trade \& Industry Information at tse.export.gov/TSE/

The share of U.S exports of manufactured goods going to Mexico as a percentage of U.S. total exports has increased from 10.1 percent to 14.5 percent over the period; while the share of total manufactured goods imported from Mexico increased from 7 percent of 12 percent. With respect to Canada, however the picture is somewhat more complex.

Historically Canada has been the number one trading partner of the United States. In 1994 Canada was the largest market for U.S. manufactured goods exports, as well as the country supplying the U.S. with the largest share of its manufactured goods imports. Over the period of the NAFTA agreement, the volume of such trade has continued to grow but not as rapidly as U.S. trade with other countries, especially China. Consequently, the share of total U.S. manufactured goods exports that go to Canada has declined from 23.1 percent to 19.4 percent, and the share of manufactured goods imported from Canada has declined from 18.6 percent to 11.9 percent.

Canada is still ranked number 1 as the market for U.S. exported manufactured goods. With respect to manufactured goods imports, however, it has fallen to fourth place in 2012, behind China with a 23.1 percent share, and Mexico with a 12.3 percent share. Thus, evidence as to the limited extent of increased economic integration between the U.S. and Canada as a result of NAFTA, in part reflects the fact that these two countries had already achieved a significant level of economic integration prior to the NAFTA agreement.

Further complicating efforts to measure the magnitude of increased economic interdependence among these three members of NAFTA is the fact that these changes are taking place in the context of the impact of other international trading agreements, including the establishment of the WTO in 1995, and hemispheric agreements such as the 2004 Dominican Republic-Central America-United States Free Trade Agreement, the 2004 United States-Chile Free Trade Agreement, the 2009 United States-Peru Trade Promotion Agreement and, most recently, the 2012 United States-Columbia Trade Promotion Agreement.

Evidence of little, if any, increased interdependence of Mexico's economy with the U.S. and Canada can be inferred from two U.S. International Trade Commission working papers. Agama and McDaniel (2002) show some increases in U.S. import demand for Mexican goods and Mexico's demand for U.S. goods based on the tariff preferences by NAFTA. They find that "since 1993 Mexico has been exporting more, not only to the U.S., but to nearly every major region in the world" (p. 10). The second paper by DeLaCruz et. al. (2011) shows a diminishing share of Mexico's exports to the world going to the U.S., declining from 90.7 percent in 2000 to 86.4 percent in 2006 while exports to Canada over the same period remained virtually unchanged at slightly above 2 percent, even as the volume of trade increased.

The lack of overwhelming evidence of significant increases in economic integration among the members of NAFTA over the years is evident from the statistical results contained in this paper. 


\section{Methodology and Data}

Comparing the financial characteristics of different groups of firms has long been a popular methodology in finance. Altman (1968), Beaver (1968), Deakin (1972), Moyer (1977), Edmister (1972), and Dambolena and Khoury (1980) predict bankruptcy by comparing the financial characteristics of bankrupt and non-bankrupt firms. Stevens (1973), Belkaoui (1978), Rege (1984), and Meric at al. (1991) identify the financial characteristics of firms that have been corporate takeover targets by comparing them with firms that have not been targets in corporate takeovers. Hutchinson at al. (1988) and Meric and Meric (1992) identify the financial characteristics of firms which achieve stock market quotation by comparing them with firms without stock market quotation. Meric at al. (2000) compare the financial characteristics of Japanese kieretsu-affiliated and independent firms to identify the financial characteristics of kieretsu-affiliated firms.

A number of studies compare the financial characteristics of firms in different countries. Kester (1986) and Wald (1999) compare the capital and ownership structures of firms in different countries and they find significant differences. Meric and Meric (1989 and 1994) compare the financial characteristics of U.S. and Japanese manufacturing firms and they find significant differences. Meric et al. (2003) find significant differences between the financial characteristics of U.S. and Canadian manufacturing firms. Meric et al. (2002) find significant differences between the financial characteristics of U.S., E.U., and Japanese manufacturing firms.

Meric et al. (2004) compare the financial characteristics of manufacturing firms within the E.U. They conclude that, despite economic integration, significant differences exist between the financial characteristics of firms in different E.U. countries. A study by Meric et al. (2007) conclude that differences between the financial characteristics of firms in different E.U. countries persist over time despite increased economic integration.

Multiple Discriminant Analysis (MDA) (see, e.g., Altman, 1968; Stevens, 1973; Belkaoui, 1978) and Multivariate Analysis of Variance-MANOVA (see, e.g., Hutchinson et al., 1988; Meric et al., 1991, 1997) are two multivariate techniques most commonly used in previous studies to compare the financial characteristics of different groups of firms. In this study, we use the MANOVA technique to compare the financial characteristics of U.S., Canadian, and Mexican manufacturing firms. Detailed information about the MANOVA methodology can be found in Marascuilo and Levin (1983) and Johnson and Wichern (2007).

Financial ratios are generally used in empirical studies to compare the financial characteristics of different groups of firms. Our firm financial ratio data were obtained from the 'Research Insight/Global Vintage' database in September 2012. Manufacturing industries with SIC codes between 2000-3999 are included in the study. Our research sample consists of 909 U.S., 81 Canadian, and 32 Mexican manufacturing firms. Our study includes all firms in the database with no missing financial data. We use the financial ratios presented in Table 2 in the comparisons of firm financial characteristics.

Table 2. Financial ratios used in the study as measures of firm financial characteristics*

\begin{tabular}{ll}
\hline Financial Ratio Name & Financial Ratio Definition \\
\hline $\begin{array}{l}\text { Liquidity } \\
\text { Current Ratio (CR) }\end{array}$ & $\begin{array}{l}\text { Current Assets / Current Liabilities } \\
\text { (Current Assets - Inventories) / Current Liabilities }\end{array}$ \\
\hline $\begin{array}{l}\text { Quick Ratio (QR } \\
\text { Accounts Receivable Turnover (ART) }\end{array}$ & Sales / Accounts Receivable \\
Inventory Turnover (INT) & Sales / Inventory \\
Fixed Assets Turnover (FAT) & Sales / Net Fixed Assets \\
Total Assets Turnover (TAT) & Sales / Total Assets \\
\hline Financial Leverage & \\
Equity Ratio (ER) & Common Equity/Total Liabilities \\
\hline Profitability & \\
Net Profit Margin (NPM) & Net Income / Sales \\
Operating Profit Margin (OPM) & Operating Income / Sales \\
Return on Assets (ROA) & Net Income / Total Assets \\
Return on Equity (ROE) & Net Income / Common Equity \\
\hline Growth & \\
Annual Sales Growth Rate (ASGR) & Average for the Last Three Years \\
\hline
\end{tabular}

Note: *The financial ratio data were obtained from the 'Research Insight/Global Vintage' database in September 2012. 


\section{Empirical Findings}

Our MANOVA test results are presented in Tables 3, 4, and 5. The multivariate test statistics in these tables indicate that the overall financial characteristics of Canadian manufacturing firms are significantly different from the financial characteristics of U.S. and Mexican manufacturing firms at the 1-percent level. The overall financial characteristics of U.S. manufacturing firms are significantly different from the financial characteristics of Mexican manufacturing firms at the 5-percent level.

\subsection{Liquidity}

The test statistics in Table 3 indicate that the liquidity ratios of U.S. manufacturing firms are significantly higher that the liquidity ratios of Canadian manufacturing firms at the 1-percent level. The test statistics in Table 4 show that the liquidity ratios of U.S. manufacturing firms are also significantly higher compared with the liquidity ratios of Mexican manufacturing firms at the 10-percent level. However, the univariate test statistics in Table 5 reveal that the liquidity ratios of Canadian and Mexican manufacturing firms are not significantly different. These results imply that U.S. manufacturing firms have less technical insolvency risk (i.e., U.S. manufacturing firms are better able to meet their maturing obligations) compared with Canadian and Mexican manufacturing firms.

\subsection{Asset Management}

The univariate test statistics in the three tables indicate that the accounts receivable turnover, inventory turnover, and total assets turnover ratios of manufacturing firms in the U.S., Canada, and Mexico are not significantly different. However, fixed assets turnover ratios of manufacturing firms in the three countries are significantly different. U.S. manufacturing firms have significantly higher fixed assets turnover ratios compared with their Canadian and Mexican counterparts (i.e., U.S. manufacturing firms use significantly smaller amounts of fixed assets compared with Canadian and Mexican manufacturing firms). The fixed assets turnover ratios of Canadian manufacturing firms are also significantly higher compared with Mexican manufacturing firms. Mexican firms appear to use significantly larger amounts of fixed asset investment in manufacturing compared with U.S. and Canadian firms.

\subsection{Debt Financing and Financial Leverage}

The univariate test statistics in Tables 3, 4, and 5 indicate that the 'common equity/ total liabilities' ratios of manufacturing firms in the three countries are not significantly different (i.e., manufacturing firms in the three countries have a similar amounts of financial risk (bankruptcy risk).

Table 3. MANOVA statistics: U.S. vs. Canada

\begin{tabular}{|c|c|c|c|c|}
\hline \multirow[t]{2}{*}{ Financial Ratios } & \multicolumn{2}{|c|}{ Means and Standard Deviations $\dagger$} & \multicolumn{2}{|c|}{ United States } \\
\hline & Univariate Statistics & Canada & F Value & $P$ Value \\
\hline \multicolumn{5}{|l|}{ Liquidity } \\
\hline Current Ratio & $3.324(2.540)$ & $2.414(1.742)$ & $9.980 * * *$ & 0.002 \\
\hline Quick Ratio & $2.231(2.245)$ & $1.487(1.403)$ & $8.601 * * *$ & 0.003 \\
\hline \multicolumn{5}{|l|}{ Asset Management (Turnover) Ratios } \\
\hline Accounts Receivable Turnover & $8.933(8.399)$ & $7.709(4.071)$ & 1.684 & 0.195 \\
\hline Inventory Turnover & $6.066(6.752)$ & $6.325(4.622)$ & 0.114 & 0.736 \\
\hline Fixed Assets Turnover & $10.160(14.545)$ & $6.283(6.634)$ & $5.648 * *$ & 0.018 \\
\hline Total Assets Turnover & $1.100(0.527)$ & $1.065(0.462)$ & 0.340 & 0.560 \\
\hline \multicolumn{5}{|l|}{ Financial Leverage } \\
\hline Common Equity/Total Liabilities & $2.261(2.716)$ & $1.895(2.165)$ & 1.395 & 0.238 \\
\hline \multicolumn{5}{|l|}{ Profitability } \\
\hline Net Profit Margin & $6.060 \%(10.062 \%)$ & $3.887 \%(10.485 \%)$ & $3.444^{*}$ & 0.064 \\
\hline Return on Assets & $5.433 \%(8.567 \%)$ & $3.613 \%(6.695 \%)$ & $3.463 *$ & 0.064 \\
\hline Return on Equity & $12.966 \%(25.786 \%)$ & $6.840 \%(12.701 \%)$ & $4.473 * *$ & 0.035 \\
\hline \multicolumn{5}{|l|}{ Growth } \\
\hline Annual Sales Growth Rate & $4.551 \%(12.466 \%)$ & $2.208 \%(12.389 \%)$ & 2.630 & 0.105 \\
\hline Multivariate Statistics: & & & $2.996 * * *$ & 0.001 \\
\hline
\end{tabular}

Notes: $\uparrow$ The figures in parentheses are the standard deviations. $* * *, * *, *$ indicate that the difference is significant at the 1 -percent, 5 -percent and 10-percent levels, respectively. 
Table 4. MANOVA statistics: U.S. vs. Mexico

\begin{tabular}{llllc}
\hline Financial Ratios & \multicolumn{2}{c}{ Means and Standard Deviations $\dagger$} & \multicolumn{2}{c}{ United States } \\
& Univariate Statistics & Canada & F Value & P Value \\
\hline Liquidity & & & & \\
Current Ratio & $3.324(2.540)$ & $2.486(1.485)$ & $3.438^{*}$ & 0.064 \\
Quick Ratio & $2.231(2.245)$ & $1.580(1.140)$ & $2.668^{*}$ & 0.103 \\
Asset Management (Turnover) Ratios & & & & \\
Accounts Receivable Turnover & $8.933(8.399)$ & $8.591(4.695)$ & 0.053 & 0.818 \\
Inventory Turnover & $6.066(6.752)$ & $6.034(2.891)$ & 0.001 & 0.978 \\
Fixed Assets Turnover & $10.160(14.545)$ & $2.593(1.159)$ & $8.651^{* * *}$ & 0.003 \\
Total Assets Turnover & $1.100(0.527)$ & $1.014(0.392)$ & 0.826 & 0.364 \\
Financial Leverage & & & & 0.113 \\
Common Equity/Total Liabilities & $2.261(2.716)$ & $1.496(1.100)$ & 2.522 & 0.432 \\
Profitability & & & & 0.618 \\
Net Profit Margin & $6.060 \%(10.062 \%)$ & $4.642 \%(9.172 \%)$ & 0.001 & 0.979 \\
Return on Assets & $5.433 \%(8.567 \%)$ & $5.393 \%(7.239 \%)$ & 0.234 & 0.629 \\
Return on Equity & $12.966 \%(25.786 \%)$ & $10.743 \%(17.946 \%)$ & & 0.138 \\
Growth & & & & $\mathbf{0 . 0 3 0}$ \\
Annual Sales Growth Rate & $4.551 \%(12.466 \%)$ & $7.868 \%(10.975 \%)$ & 2.205 & $\mathbf{1 . 9 5 4 * *}$ \\
Multivariate Statistics: & & & \\
\hline
\end{tabular}

Notes: $\uparrow$ The figures in parentheses are the standard deviations. ${ }^{* * *}, * *, *$ indicate that the difference is significant at the 1-percent, 5 -percent and 10-percent levels, respectively.

Table 5. MANOVA statistics: Canada vs. Mexico

\begin{tabular}{|c|c|c|c|c|}
\hline \multirow[t]{2}{*}{ Financial Ratios } & \multicolumn{2}{|c|}{ Means and Standard Deviations $\dagger$} & \multicolumn{2}{|c|}{ United States } \\
\hline & Univariate Statistics & Canada & F Value & P Value \\
\hline \multicolumn{5}{|l|}{ Liquidity } \\
\hline Current Ratio & $2.414(1.742)$ & $2.486(1.485)$ & 0.043 & 0.836 \\
\hline Quick Ratio & $1.487(1.403)$ & $1.580(1.140)$ & 0.111 & 0.739 \\
\hline \multicolumn{5}{|l|}{ Asset Management (Turnover) Ratios } \\
\hline Accounts Receivable Turnover & $7.709(4.071)$ & $8.591(4.695)$ & 0.984 & 0.323 \\
\hline Inventory Turnover & $6.325(4.622)$ & $6.034(2.891)$ & 0.110 & 0.741 \\
\hline Fixed Assets Turnover & $6.283(6.634)$ & $2.593(1.159)$ & $9.730 * * *$ & 0.002 \\
\hline Total Assets Turnover & $1.065(0.462)$ & $1.014(0.392)$ & 0.294 & 0.589 \\
\hline \multicolumn{5}{|l|}{ Financial Leverage } \\
\hline Common Equity/Total Liabilities & $1.895(2.165)$ & $1.496(1.100)$ & 0.981 & 0.324 \\
\hline \multicolumn{5}{|l|}{ Profitability } \\
\hline Net Profit Margin & $3.887 \%(10.485 \%)$ & $4.642 \%(9.172 \%)$ & 0.127 & 0.722 \\
\hline Return on Assets & $3.613 \%(6.695 \%)$ & $5.393 \%(7.239 \%)$ & 1.547 & 0.216 \\
\hline Return on Equity & $6.840 \%(12.701 \%)$ & $10.743 \%(17.946 \%)$ & 1.695 & 0.196 \\
\hline \multicolumn{5}{|l|}{ Growth } \\
\hline Annual Sales Growth Rate & $2.208 \%(12.389 \%)$ & $7.868 \%(10.975 \%)$ & $5.094 * *$ & 0.026 \\
\hline Multivariate Statistics: & & & $2.688 * * *$ & 0.005 \\
\hline
\end{tabular}

Notes: $\uparrow$ The figures in parentheses are the standard deviations. ${ }^{* * *},{ }^{* *}, *$ indicate that the difference is significant at the 1-percent, 5 -percent and 10-percent levels, respectively.

\subsection{Profitability}

The univariate test statistics in Tables 4 and 5 indicate that the profitability ratios of Mexican manufacturing firms are not significantly different from the profitability ratios of U.S. and Canadian manufacturing firms. However, the test statistics in Table 3 show that the return-on-equity ratios of U.S. manufacturing firms are significantly higher than the return-on-equity ratios of Canadian manufacturing firms at the 5-percent level. The U.S. net-profit-margin and return-on-assets ratios are also significantly higher than the Canadian ratios at the 10-percent level. 


\subsection{Growth}

The mean annual sales growth rate is the highest for Mexican manufacturing firms (about 7.9\%) and the lowest for Canadian manufacturing firms (about 2.2\%). It is about 4.6\% for U.S. manufacturing firms. The standard deviation figure is quite large for all three countries. Therefore, the U.S. growth rate is not significantly different from the Canadian and Mexican growth rates. However, the Mexican growth rate is significantly higher than the Canadian growth rate at the 5 -percent level.

\section{Summary and Conclusions}

In this paper, we compare the financial characteristics of U.S., Canadian, and Mexican manufacturing firms with the MANOVA (Multivariate Analysis of Variance) methodology. We use twelve financial ratios in the comparisons as measures of liquidity, asset management, indebtedness, profitability, and growth characteristics of the firms. The data of the study were obtained from the 'Research Insight/Global Vintage' database in September 2012. Our research sample includes 909 U.S., 81 Canadian, and 32 Mexican manufacturing firms with SIC codes between 2000-3999.

Our multivariate test statistics indicate that the overall financial characteristics of U.S. manufacturing firms are significantly different from Canadian manufacturing firms at the 1 percent level and from Mexican manufacturing firms at the 5 percent level. The overall financial characteristics of Canadian and Mexican firms are also significantly different at the 1 percent level.

Our univariate test statistics show that the liquidity ratios of U.S. manufacturing firms are significantly higher compared with the liquidity ratios of Canadian manufacturing firms at the 1 percent level and Mexican manufacturing firms at the 10 percent level. The differences between the liquidity ratios of Canadian and Mexican manufacturing firms are not statistically significant. These results imply that U.S. manufacturing firms have less technical insolvency risk (i.e., U.S. firms are better able to meet their maturing obligations) compared with their Canadian and Mexican counterparts.

The accounts receivable turnover, inventory turnover, and total assets turnover ratios of manufacturing firms in the three countries are not significantly different. However, U.S. manufacturing firms have significantly higher fixed assets turnover ratios compared with their Canadian and Mexican counterparts (i.e., U.S. manufacturing firms use significantly smaller amounts of fixed asset investment in manufacturing compared with Canadian and Mexican manufacturing firms).

The univariate tests reveal that the indebtedness of manufacturing firms in the three countries are not significantly different (i.e., manufacturing firms in the three countries have similar bankruptcy risk).

The return-on-equity ratios are significantly higher in the U.S. than in Canada at the 5-percent level. The U.S. net-profit-margin and return-on-assets ratios are also higher than the Canadian ratios at the 10-percent level. The profitability ratios of Mexican manufacturing firms are not significantly different from those of U.S. and Canadian manufacturing firms.

The U.S. sales growth rate is not significantly different from the Canadian and Mexican sales growth rates. However, the Mexican sales growth rate is significantly higher than the Canadian sales growth rate at the 5-percent level.

The U.S., Canada, and Mexico are members of NAFTA since 1994. A major objective of NAFTA has been to promote economic integration among the three countries. Empirical studies show that financial characteristics of firms in different countries tend to become similar with economic integration. In this study, we find that the overall financial characteristics of U.S., Canadian, and Mexican manufacturing firms are significantly different. From our findings in this study, one may conclude that either the life of NAFTA has not been long enough to assure full economic integration or the provisions of NAFTA have not been strong enough to promote stronger integration among the three countries.

\section{References}

Agama, L., \& McDaniel, C. A. (2002). The NAFTA Preference and U.S.-Mexico Trade. Working Paper No. 2002-10-A of Office of Economics, U.S. International Trade Commission.

Aggarwal, R., \& Kyaw, N. A. (2005). Equity Market Integration in the NAFTA Region: Evidence from Unit Root and Co-Integration Tests. International Review of Financial Analysis, 14(4), 393-406. http://dx.doi.org/10.1016/j.irfa.2004.10.008

Altman, E. I. (1968). Financial Ratios, Discriminant Analysis, and the Prediction of Corporate Bankruptcy. Journal of Finance, 23(4), 589-609. http://dx.doi.org/10.1111/j.1540-6261.1968.tb00843.x 
Beaver, W. H. (1968). Alternative Financial Ratios as Predictors of Failure. Accounting Review, 43(1), 113-122.

Belkaoui, A. (1978). Financial Ratios as Predictors of Canadian Takeovers. Journal of Business Finance and Accounting, 5(1), 93-108. http://dx.doi.org/10.1111/j.1468-5957.1978.tb00177.x

Dambolena, I. G., \& Khoury, S. J. (1980). Ratio Stability and Corporate Failure. Journal of Finance, 35(4), 1017-1026. http://dx.doi.org/10.1111/j.1540-6261.1980.tb03517.x

Deakin, E. B. (1972). A Discriminant Analysis of Predictors of Business failure. Journal of Accounting Research, 10(1), 167-179. http://dx.doi.org/10.2307/2490225

DeLaCruz, J., Koopman, R. B.,Wang, Z., \& Wei, S. (2011). Estimating Foreign Value-added in Mexico's Manufacturing Exports. Working Paper No. 2011-04A of Office of Economics, U.S. International Trade Commission.

Edmister, R. O. (1972). An Empirical Test of Financial Ratio Analysis for Small Business Failure Prediction. Journal of Financial and Quantitative Analysis, 7(2), 1477-1493. http://dx.doi.org/10.2307/2329929

Gultekin, M. N., Gultekin, N. B., \& Penati, A. (1989). Capital Controls and International Capital Market Segmentation: The Evidence from the Japanese and American Stock Markets. Journal of Finance, 44(4), 849-870. http://dx.doi.org/10.1111/j.1540-6261.1989.tb02627.x

Hillberry, R. H., \& McDaniel, C. A. (2002). A Decomposition of North American Trade Growth since NAFTA. Working Paper No. 2002-12-A of Office of Economics, U.S. International Trade Commission.

Hufbaurer, G. C., \& Schott, J. J. (2005). NAFTA Revisited: Achievements and Challenges. Washington, D. C. Institute for International Economics.

Hutchinson, P., Meric, I., \& Meric, G. (1988). The Financial Characteristics of Small Firms which Achieve Quotation on the UK Unlisted Securities Market. Journal of Business Finance and Accounting, 15(1), 9-19. http://dx.doi.org/10.1111/j.1468-5957.1988.tb00116.x

Johnson, R. D., \& Wichern, D. W. (2007). Applied Multivariate Statistical Analysis (6th ed.). Englewood Cliffs, NJ: Prentice Hall.

Karemera, D., \& Ojah, K. (1998). An Industrial Analysis of Trade Creation and Diversion Effects of NAFTA. Journal of Economic Integration, 13(3), 400-425. http://dx.doi.org/10.11130/jei.1998.13.3.400

Kester, W. C. (1986). Capital and Ownership Structure: A Comparison of United States and Japanese Manufacturing Firms. Financial Management, 15(1), 5-16. http://dx.doi.org/10.2307/3665273

Marascuilo, L. A., \& Levin, J. R. (1983). Multivariate Statistics in the Social Sciences. Monterey, California: Brooks/Cole Publishing Company.

Meric, G., \& Meric, I. (1992). A Comparison of the Financial Characteristics of Listed and Unlisted Companies. Mid-Western Journal of Business and Economics, 7(1), 19-31.

Meric, G., Kyj, L., Welch, C., \& Meric, I. (2000). A Comparison of the Financial Characteristics of Japanese Kieretsu-Affiliated and Independent Firms. Multinational Business Review, 8(2), 26-30.

Meric, G., Leveen, S. S., \& Meric, I. (1991). The Financial Characteristics of Commercial Banks Involved in $\begin{array}{lllll}\text { Interstate } & \text { Acquisitions. } & \text { Financial } & \text { Review, } & \text { 26(1), }\end{array}$ http://dx.doi.org/10.1111/j.1540-6288.1991.tb00370.x

Meric, I., \& Meric, G. (1989). A Comparison of the Financial Characteristics of U.S. and Japanese Manufacturing Firms. Financial Management-FM Letters, 18(4), 9-10. http://dx.doi.org/10.2307/3665789

Meric, I., \& Meric, G. (1994). A Comparison of the Financial Characteristics of United States and Japanese $\begin{array}{llll}\text { Manufacturing Firms. Global Finance } & \text { Journal, }\end{array}$ http://dx.doi.org/10.1016/1044-0283(94)90004-3

Meric, I., Gishlick, H. E., McCall, C. W., \& Meric, G. (2003). A Comparison of the Financial Characteristics of U.S. and Canadian Manufacturing Firms. Midwestern Business and Economic Review, 31(1), 25-33.

Meric, I., Gishlick, H. E., Taga, L. S., \& Meric, G. (2007). The Effects of Economic Integration on the Financial Characteristics of E.U. Manufacturing Firms: 1990-2004. Southwest Business and Economics Journal, 15(1), 1-8.

Meric, I., Prober, L., Eichhorn, B., \& Meric, G. (2004). Integration and the Financial Characteristics of Manufacturing Firms in the European Union. American Business Review, 22(2), 88-96. 
Meric, I., Ross, L., Weidman, S., \& Meric, G. (1997). A Comparison of the Financial Characteristics of U.S. and Japanese Chemical Firms. Multinational Business Review, 5(2), 23-27. http://dx.doi.org/10.2307/3665489

Meric, I., Weidman, S. M., Welsh, C. N., \& Meric, G. (2002). A Comparison of the Financial Characteristics of U.S., E.U., and Japanese Manufacturing Firms. American Business Review, 20(2), 119-125.

Moyer, R. C. (1977). Forecasting Financial Failure: A Re-examination. Financial Management, 6(1), 11-17.

Rege, U. P. (1984). Accounting Ratios to Locate Take-over Targets. Journal of Business Finance and Accounting, 11(3), 301-311. http://dx.doi.org/10.1111/j.1468-5957.1984.tb00751.x

Stevens, D. L. (1973). Financial Characteristics of Merged Firms: A Multivariate Analysis. Journal of Financial and Quantitative Analysis, 8(2), 149-158. http://dx.doi.org/10.2307/2330007

Stulz, R. M. (1981). On the effects of barriers to international investment. Journal of Finance, 36(4), 923-934. http://dx.doi.org/10.1111/j.1540-6261.1981.tb04893.x

Wald, J. K. (1999). How Firm Characteristics Affect Capital Structure: An International Comparison. Journal of Financial Research, 22(2), 161-187.

Wylie, P. J. (1995). Partial Equilibrium Estimates of Manufacturing Trade Creation and Diversion Due to NAFTA. North American Journal of Economics and Finance, 6(1), 65-84. http://dx.doi.org/10.1016/1062-9408(95)90006-3

\section{Copyrights}

Copyright for this article is retained by the author(s), with first publication rights granted to the journal.

This is an open-access article distributed under the terms and conditions of the Creative Commons Attribution license (http://creativecommons.org/licenses/by/3.0/). 